\title{
Outcomes of Total Surgical Correction for Tetralogy of Fallot in Benghazi
}

\author{
Marium Mohamed Mustafa ${ }^{*}$, Rasmyia H. Elfatory, Aziza I. Gadwar, Khadija imhemed \\ elshreef and Hagir M.Alshabi
}

Department of Pediatric, Faculty of Medicine, Benghazi University, Benghazi cardiac center, Libya

Received: 19 January 2020/ Accepted: 25 December 2020

Doi: https://doi.org/10.54172/mjsc.v35i3.252

\begin{abstract}
Tetrology of Fallot (TOF) is the most common cyanotic congenital heart disease, accounting for $10 \%$ of all types of congenital heart disease. Despite decreased mortality rates by improvement in surgery and post-cardiac intensive care, there continues to be late postoperative complications. This study aimed to evaluate the outcomes after total repair of tetralogy of Fallot, including 44 children who underwent complete surgical repair between 2000 to 2018. Data were collected from medical records and directly from patients during their visit to the clinic, that included: history, clinical examination, gender, age at operation, results of ECG, Holter monitoring, echocardiography, cardiac catheterization, cardiac CT scan. Follow-up ranged from 6 months to18 years. Results revealed that the M/F ratio was $1.4: 1$. Also, two patients had a previous palliative systemic artery to PA shunt. A TAP was inserted in $22(50 \%)$ patients. Postoperative complications were: severe PR 29\%, small residual VSD 18.1\%, and two patients had significant VSD which needed surgical intervention, residual RVOT $8.1 \%$, RBBB $97.7 \%$, There was three death (6.8\%), and $36.3 \%$ of patients will need surgical intervention in the future. It was concluded that follow-ups up to adulthood to monitor potential complications are necessary. QRS duration is used for monitoring ventricular arrhythmia and sudden death. Echocardiography is a non-invasive tool in diagnosis, before and at the time of surgery, as well as in follow-ups.
\end{abstract}

Keywords: Tetralogy of Fallot, congenital heart disease, surgery, Benghazi.

\section{INTRODUCTION}

Tetrology of Fallot (TOF) is the most common cyanotic congenital heart disease, accounting for $10 \%$ of all types of congenital heart disease with $0.23-0.63$ cases per 1,000 births. It is composed of the overriding of the interventricular septum, which results in 4 abnormalities: sub pulmonary stenosis, ventricular septal defect (VSD), right ventricular hypertrophy, Aorta overriding of the interventricular septum (h Anderson \& m Weinberg, 2005). The postnatal presentation is depending on the severity of RVOT obstruction. Severe obstruction leads to severe cyanosis in the neonatal period, which need prostaglandin therapy to maintain the patency of the ductus arte- riosus. This will improve pulmonary blood flow, thus avoiding life-threatening cyanosis. It should then be followed by urgent palliative systemic artery to PA shunt (B-T shunt) (Kanter et al., 2010). Potential disadvantages of BT shunt include continuous pressure overload of the RV and persistent cyanosis. This leads to RV hypertrophy and hypoxemia, which contributes to cardiomyocyte degeneration and interstitial fibrosis, which have been implicated in myocardial dysfunction and arrhythmias and it is reserved for those presenting with severe cyanosis or specific anatomical features such as the presence of coronary abnormalities (left anterior descending artery arising from the right coronary artery and crossing the RVOT, the exist- 
ence of multiple VSDs, and inadequate PA size(Bhardwaj et al., 2017)

The optimal timing for elective complete repair is 4 to 8 months of age. With the use of TAP, there is a decrease in residual pulmonary stenosis with an increase of pulmonary regurgitation, which lead to right heart dilation and dysfunction that need PV replacement later on (Shahanavaz et al., 2018). Infundibulotomy, resection of obstructive muscle bundles, and the use of a TAP to enlarge the pathway from the right ventricle to the Pas result in scar tissue and a noncontracting RVOT, which may progress to aneurysm (Naidu et al., 2017). There is also a risk of aortic root and ascending aorta dissection due to chronic $\mathrm{AR}$, right ventricular dysfunction and dilatation, and PA stenosis. These complications need monitoring by ECG where RBBB with prolongation of QRS complex is nearly universal (Smith et al., 2019). Arrhythmias, ventricular tachycardia, atrioventricular block, atrial flutter or fibrillation, are seen with increased frequency in the third and fourth decades of life. They increase the risk of sudden death to $2 \%$ per decade (Wu et al., 2018). All children need follow-up postoperatively up to adulthood for monitoring potential complications that may necessitate early intervention.

Therefore, this study was conducted to evaluate the outcomes of the surgical repair of TOF.

\section{MATERIALS AND METHODS}

In this study, all children less than 18years of age underwent surgical repair of TOF. The follow-up period ranged from 3 months to 18 years, in a cardiac clinic either at Benghazi Cardiac Center or AL-Hawary Hospital. Data was collected from medical records and directly from patients during their visit to the cardiac clinic including; history, clinical examination, gender, age at operation, type of surgery (TAP, plasty to main pulmonary ar- tery and its branches, right ventricle outlet patch, BT shunt), results of; ECG for arrhythmia and conduction abnormality, Holter monitoring (symptomatic patients), echocardiography for (pulmonary dilation, Right ventricle dilation, Tricuspid regurgitation, residual VSD, RVOTO, Aortic incompetence, and LVOLO), catheterization (3patients), and CT angiography (4 patients). Patients with pulmonary atresia, absent pulmonary valve, atrioventricular septal defects, and ASD were excluded from the study.

Descriptive statistics were used in data analysis. Data was analyzed manually, put in tables and presented as numbers and percentages.

\section{RESULTS}

A total of 44 child operated for TOF. 26 $(59 \%)$ were male, and $18(40.9 \%)$ were female with an $\mathrm{M} / \mathrm{F}$ ratio of 1.4:1 (Table-1). Their age at operation ranged from 6 months to 17 years (Table-2). TAP was the most common surgical procedure used in $22(50 \%)$ patients, and two patients had previous palliative shunts (Table-3).

Table (1): Sex Distribution.

\begin{tabular}{lll}
\hline \hline Sex & NO & $\%$ \\
\hline Male & 26 & $59 \%$ \\
Female & 18 & $40.9 \%$ \\
\hline \hline
\end{tabular}

Table (2): Age at Time of Operation.

\begin{tabular}{ll}
\hline \hline Age & No, $(\mathbf{\%})$ \\
\hline$<1$ year & $4(9 \%)$ \\
$\geq 1-2$ years & $17(38.6 \%)$ \\
$\geq 2-3$ years & $9(20.4 \%)$ \\
$\geq 3-4$ years & $3(6.8 \%)$ \\
$>4$ years & $11(25 \%)$ \\
\hline \hline
\end{tabular}

Table (3): Type of Operation.

\begin{tabular}{lll}
\hline \hline Type & NO & \% \\
\hline TAP & 22 & 50 \\
TAP with RVOT Patch & 16 & 36.3 \\
RVOT Patch & 3 & 6.8 \\
$\begin{array}{l}\text { BT shunt } \\
\text { plasty to pulmonary } \\
\text { branches }\end{array}$ & 2 & 4.5 \\
\hline \hline
\end{tabular}


Regarding postoperative complications, residual VSD was found in 8 patients, among them 6 small or tiny. Two were moderate VSD, which needed surgical intervention. Moderate to severe pulmonary valve regurgitation was detected in $13(29.5 \%)$ patients, among them, 5 had RVOT Aneurysm, and all of them needed surgical intervention. Moderate tricuspid regurgitation occurred in 6 (11.3\%) patients. RVOT obstruction with a pressure gradient of more than $40 \mathrm{mmHg}$ was detected in $8(18.1 \%)$ patients.

$3(6.8 \%)$ patients died after surgery; 2 within 30 days after surgery, one after one year with severe PR and right ventricle failure (Table $4)$. $\mathrm{RBBB}$ in $97.7 \%$ bigeminy $2.3 \%$, infrequent ventricular ectopic $4.5 \%$ (Tabel-5, 6).

Table (4): postoperative complications.

\begin{tabular}{cll}
\hline \hline Complication & NO & \multicolumn{1}{c}{$\%$} \\
\hline Residual TR & 12 & 22.7 \\
- Trivial & 6 & 11.3 \\
- Moderate & 6 & 11.3 \\
Residual PR & 13 & 29.5 \\
Residual VSD & 8 & 18.1 \\
- Trivial to small & 6 & 13.6 \\
- Moderate to large & 2 & 4.5 \\
Residual RVOT obstruction * & 8 & 18.1 \\
Severe pulmonary stenosis & 3 & 6.8 \\
Death & 3 & 6.8 \\
\hline
\end{tabular}

* Residual RVOT obstruction $>40 \mathrm{mmHg}, \quad 16 \%$ need reintervention.

Table (5): Types of arrhythmia by ECG (No.44).

\begin{tabular}{lll}
\hline \hline Type & NO & $\%$ \\
\hline RBBB & 41 & 97.7 \\
QRS $>180 \mathrm{~ms}$ & 2 & 4.5 \\
Bigeminy & 1 & 2.3 \\
\hline \hline
\end{tabular}

Table (6): Types of arrhythmia by Holter monitor (No.4).

\begin{tabular}{lll}
\hline \hline Type & NO & $\%$ \\
\hline Infrequent unifocal VE & 2 & 4.5 \\
Multi focal VE & 1 & 2.3 \\
VT & 1 & 2.3 \\
\hline \hline
\end{tabular}

\section{DISCUSSION}

TOF is the most common cyanotic congenital heart disease accounting for $10 \%$ of all types of congenital heart disease with and with male predominance. Male to female ratio was 1.3:1 (Konstandina et al), 1.4:1(Smith et al., 2019). For 30 years, primary repair has become the standard of care, and it is recommended within the first 12 months of life. Giving excellent results in most centers with long term survivors living up to adulthood. As recommended in developed counties, the operation is performed early in infancy, while in developing countries, it is performed at an older age (Lee et al., 2004)The median age for the operation was 8 months in Bangladesh (Zheng et al., 2013) while in Macedonia it was 5 years (Hashemzadeh \& Hashemzadeh, 2010), and 9.5 years in a study by (Waqar et al., 2017).

In this study, males predominated females with an $\mathrm{M} / \mathrm{F}$ ratio of $1.4: 1$. This is similar to previous researches, but they are operated on at an older age due to: a delayed diagnosis, many patients were referred from outside Benghazi, and the lack of surgery facilities (there was a dependence on foreign cardiac surgery missions). Approximately $5 \%$ of children need a reoperation due to various causes such as residual ventricular septal defects and residual RV outflow tract obstruction. Children with a TAP operation may develop varying degrees of pulmonary insufficiency later in life which leads to RV overload, RV distention, and failure.(Zheng et al., 2013).

Various studies reported different results for TAP operation outcomes in (Ho et al., 2007) work where TAP was used in $38 \%$ of patients. after 36 years severe PR developed in $14 \%$ of them, which is less than the number of cases described by (Lee et al., 2004) where TAP was used in $48.7 \%$ of operated cases, and $56.9 \%$ of them developed moderate PR after 10 years of follow-up.

In this study, TAP was used in $50 \%$ of patients. $29.5 \%$ of them developed moderate

(C) 2020 The Author(s). This open access article is distributed under a CC BY-NC 4.0 license.

ISSN: online 2617-2186 print 2617-2178 
PR, which similar to what was reported by(Zheng et al., 2013), where $73.2 \%$ of cases were operated on by TAP, and $23.2 \%$ of them developed moderate to severe PR.

VSDs are seen postoperatively in $2 \%$ of patients; insignificant residual small VSDs are common, and large VSDs are poorly tolerated due to volume overload. Also, when shunt is $2: 1$, it is an indication for reoperation (Waqar et al., 2017) and it is reported in $9.9 \%$ of patients in (Zheng et al., 2013) study.

RVOT obstruction with pressure measuring more than $40 \mathrm{mmHg}$ is another problem, seen in $5.2 \%$ of patients in(Waqar et al., 2017), and $16 \%$ of cases in the study by(Sirivella \& Gielchinsky, 2014). In comparison, 8 patients in the current study developed residual VSD postoperatively, where 6 were small, and 2 were large and needed reoperation. RVOT obstruction was seen in 7 patients.

Injury to the right bundle branch leads to RV hypertrophy with RBBB. The longer the QRS interval, the larger the RV mass and volume will be. When it is longer than 180 milliseconds $(\mathrm{ms})$ with a rapid increase $>3.5 \mathrm{~ms} / \mathrm{yr}$, there is a significant risk of ventricular arrhythmias and sudden death, as (Scalone et al., 2017) reported these complication in $5 \%$ of their patients at a later stage of life with an unknown cause. Vehmeijer JT et al. reported right ventricular dilation associated with this complication.

This is similar to the current study where 4.5 $\%$ of patients after many years of their surgery, were complaining of chest pain, had prolonged QRS, ventricular ectopic, right ventricular dilatation, and severe pulmonary regurgitation. RBBB was reported in $97.7 \%$ of the cases, similar to (Shahanavaz et al., 2018), who studied 46 patients, all of which had RBBB. The survival rate of $92.2 \%$ in this current study, is near to (Zheng et al., 2013) where it is $96.4 \%$, and also $93.1 \%$ in (Karl \& Stocker, 2016) study.

\section{CONCLUSION}

All children need follow-up for an extended period and up to adulthood after a TOF repair to monitor potential complications that may necessitate early intervention. QRS duration is used in monitoring patients as a predictor of ventricular arrhythmia and sudden death. Echocardiography is a non-invasive tool during diagnosis, before and at the time of surgery, in addition to follow-up.

\section{REFERNCES}

Bhardwaj, V., Kapoor, P. M., Irpachi, K., Ladha, S., \& Chowdhury, U. K. (2017). Basic arterial blood gas biomarkers as a predictor of mortality in tetralogy of Fallot patients. Annals of cardiac anaesthesia, 20(1), 67 .

h Anderson, R., \& m Weinberg, P .(2005) .The clinical anatomy of tetralogy of Fallot. Cardiology in the Young, 15(s1), 38 .

Hashemzadeh, K., \& Hashemzadeh, S. (2010). Early and late results of total correction of tetralogy of Fallot. Acta Medica Iranica, 117-122 .

Ho, K. W., Tan, R. S ‘.Wong, K. Y., Tan, T. H., Shankar, S., \& Le Tan, J. (2007). Late complications following tetralogy of Fallot repair: the need for long-term follow-up. Annals-Academy of Medicine Singapore, 36(11), 947.

Kanter, K. R., Kogon, B. E., Kirshbom, P. M., \& Carlock, P. R. (2010). Symptomatic neonatal tetralogy of Fallot: repair or shunt? The Annals of thoracic surgery, 89(3), 858-863.

Karl, T. R., \& Stocker, C. (2016). Tetralogy of Fallot and its variants. Pediatric critical care medicine, 17(8), S330-S336.

Lee, J. R., Kim, J. S., Lim, H. G., Hwang, H. Y., Kim, Y. J., Rho, J. R., \& Ahn, C. (2004). Complete repair of tetralogy of 
Fallot in infancy. Interactive cardiovascular and thoracic surgery, 3(3), 470-474 .

Naidu, P., Grigg, L., \& Zentner, D. (2017). Mortality in adults with congenital heart disease. International Journal of Cardiology, 245, 125-130 .

Scalone, G., Gomez-Monterrosas, O., Fiszer, R., Szkutnik, M., Gałeczka, M., \& Białkowski, J. (2017). Combined strategy of Waterston shunt percutaneous occlusion and medical treatment with sildenafil for management of pulmonary hypertension in an adult patient with corrected tetralogy of Fallot. Advances in Interventional Cardiology/Postepy $w$ Kardiologii Interwencyjnej, 13(3), 277278 .

Shahanavaz, S., Qureshi, A. M., Levi, D. S., Boudjemline, Y., Peng, L. F., Martin, M. H., Bauser-Heaton, H., Keeshan, B., Asnes, J. D., \& Jones, T. K. (2018). Transcatheter pulmonary valve replacement with the melody valve in small diameter expandable right ventricular outflow tract conduits. JACC: Cardiovascular Interventions, 11(6), 554-564.

Sirivella, S., \& Gielchinsky, I. (2014). Early and long term outcomes of corrective operations for tetralogy of Fallot: an experience of two centers. World Journal of Cardiovascular Surgery, 4(11), 186 .

Smith, C. A., McCracken, C., Thomas, A. S., Spector, L. G., Oster, M. E., Moller, J. H., \& Kochilas, L. (2019). Long-term outcomes of tetralogy of Fallot: a study from the pediatric cardiac care consortium. JAMA cardiology, 4(1-34 ، .41

Waqar, T., Riaz, M. U., \& Mahar, T. (2017).

Tetralogy of Fallot repair in patients
Wu, M. H., Lu, C. W., Chen, H. C., Kao, F. Y., \& Huang ‘S. K. (2018). Adult congenital heart disease in a Nationwide population 2000-2014: epidemiological trends, arrhythmia, and standardized mortality ratio. Journal of the American Heart Association, 7(4), $\mathrm{e} 007907$.

Zheng, D.-w., Shao, G.-f., Feng, Q., \& Ni. Y.m. (2013). Long-term outcome of correction of tetralogy of Fallot in 56 adult patients. Chinese medical journal, 126(19), 3675-3679 


\section{نتائج جراحة الإصلاح الكامل لرياعية فالوت في بنغازي}

مريم محمد مصطفي المعدانى"، رسميه حسني الفيتوري، عزيزة عزلاين قظوار، خديجة امحمد الثريف وهاجر شلبي

قسم طب الأطفال، كلية الطب البشري، جامعة بنغازي، مركز القلب في بنغازي، ليبيا

تاريخ الاستلام: 19 يناير 2020/ ناريخ القبول: 25 ديسمبر 2020 /D35i3.252 https://doi.org/10.54172/mjsc.v35i3.252:Doi

المستخلص: رباعية فالوت هو من أكثر أمراض القلب الخلقية شيوعا والتي تمثل 10 ٪ من أمراض القلب الخلقية. على الرغم من انخفاض معدلات وفيات مرضى رباعي فالوت نتيجة لتحسن في الجراحة والعناية المركزة للقلب. لا تزال هنالك مضاعفات متأخرة بعد العملية الجراحية. تهدف هذه الدراسة المستقبلية إلى تقييم النتائج بعد الإصلاح الكامل لعملية رباعية فالوت لـ 44 من الأطفال

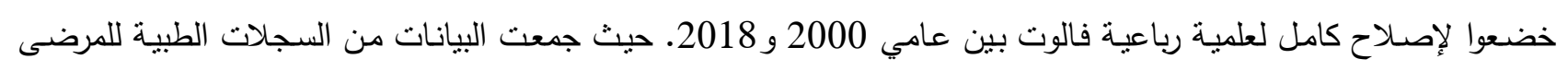
ومن المرضى مباشرة خلال زيارتهم لعيادة القلب بما في ذلك: التاريخ المرضى، الفحص السريرى والجنس والعمر عند اجراء

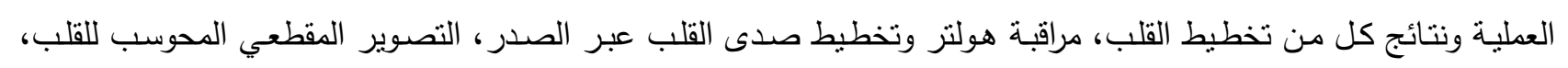
قسطرة القلب. فترة متابعة المريض بعد العملية تتراوح من 6 شهور إلى 18 سنة، كثفت النتائج أن نسبة الذكور إلى الإناث كانت

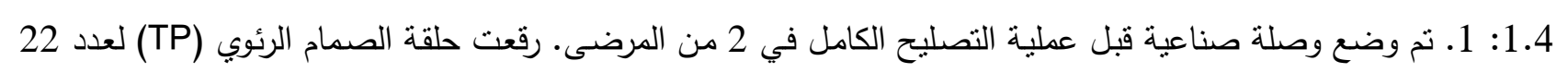

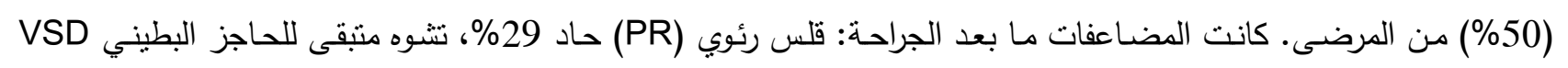
18.1\%، وكذلك فإن اثثين فقط من المرضى كان لديهم فتحه كبيرة منتقية تحتاج إلى تدخل جراحي، وانسداد منتقى لمخرج البطين

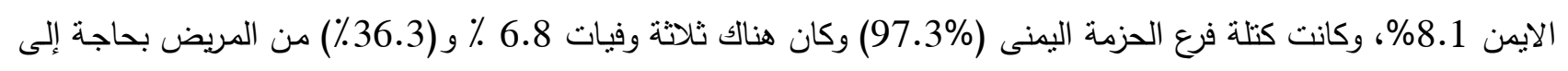
تدخل في المستقبل. نستتتج أنه يجب متابعه المرضى حتى سن البلوغ للكثف عن المضاعفات المحتملة، واستخدام تخطيط القلب لرصد اضطراب نظم القلب والموت المفاجئ، أن تخطيط صدى القلب هو أداة غير جراحيـة تلزم في التشخيص وفيل فئل وأثناء الجراحة وكذلك في المتلبعة.

الكلمات المفتاحية: رباعي فالوت، أمراض القلب الخلقية، جراحة، بنغازي. 